\title{
THE "LORD COOKE PROJECT": REVIEWING LORD COOKE'S EXTRAJUDICIAL WRITING
}

\author{
Tim Cochrane and Elizabeth Chan*
}

\begin{abstract}
This note discusses key themes arising from Lord Cooke's published extrajudicial writing. These themes cover Lord Cooke's conception of the common law, the interpretation of the Treaty of Waitangi, the development of bill of rights jurisprudence in New Zealand and overseas, and the role of judges. This note arises out of the authors' involvement in the Lord Cooke project, a Victoria University of Wellington initiative that will make a complete collection of Lord Cooke's extrajudicial writings available online.
\end{abstract}

\section{INTRODUCTION}

Baron Cooke of Thorndon, previously known as the Rt Hon Sir Robin Cooke (and referred to throughout this note as Lord Cooke), is widely regarded as one of New Zealand's greatest judges. ${ }^{1}$ As both an advocate and a judge, Lord Cooke made a monumental contribution to many areas of law. He issued significant judgments in a diverse range of areas, especially in public law and Treaty of Waitangi jurisprudence. However, he made an equally significant contribution through his extrajudicial writing, which spans more than 50 years across the 20th and 21 st centuries and has been described as "prodigious". ${ }^{2}$ In our review of Lord Cooke's extrajudicial writing, we identify and comment on a selection of themes emerging from Lord Cooke's published papers.

This note arises out of our involvement in the "Lord Cooke Project". This is a Victoria University of Wellington project that aims to make available online an (eventually) complete collection of Lord Cooke's extrajudicial writing, including book chapters, journal articles, speeches, book reviews and other material, as well as previously unpublished papers. Using the Social Science

* Tim Cochrane is a solicitor at Kensington Swan and Elizabeth Chan is a judge's clerk at the Supreme Court of New Zealand. This note is based primarily on our review so far of Lord Cooke's published papers.

1 See for example, the comments expressed by authors to the commemorative issue of this journal honouring Lord Cooke in (2008) 39 VUWLR.

2 ATH Smith "Lord Cooke and Cambridge" (2008) 39 VUWLR 27 at 37. 
Research Network (SSRN) platform, the Lord Cooke Project will provide access to Lord Cooke's published and unpublished work, with abstracts of his writing accompanied by electronic copies of each article, where copyright permits. The Lord Cooke Project is led by Professor John Prebble and Dr Joel Colón-Ríos of Victoria University, with research assistance provided by the authors of this note. The project complements a similar project undertaken at Victoria University for the writings of Sir Ivor Richardson. The results of the Lord Cooke Project are available for free online. ${ }^{3}$

Following a discussion of the value of extrajudicial writing, this focuses on three key themes that appear throughout Lord Cooke's published works. First, it discusses Lord Cooke's conception of the common law, which evolved significantly throughout his career. Secondly, the note drills down into two particular aspects of public law (the field in which Lord Cooke is considered by many to have had the most influence): ${ }^{4}$ his views on the courts' interpretation of the Treaty of Waitangi and his support for the New Zealand Bill of Rights Act 1990 (NZBORA). Finally, it closes by describing Lord Cooke's understanding of the role of judges. In this part, we examine Lord Cooke's advocacy for clarity in the law as a guiding principle of interpretation, as well as his critique of parliamentary sovereignty.

These themes are informed by Lord Cooke's varied judicial career. He served as a judge of the Supreme Court (as the High Court was previously called), the Court of Appeal (becoming President of this Court in 1986), and finally in the United Kingdom as a Law Lord of the House of Lords and concurrently as a member of the Judicial Committee of the Privy Council. While in these latter appellate judicial roles, Lord Cooke also travelled on circuit to the final appellate courts of Samoa, the Cook Islands, Kiribati, Fiji, and Hong Kong. As is clear from his extrajudicial comments, Lord Cooke frequently drew on the experience and expertise of not only these courts but also the courts of other jurisdictions, including the courts of Australia, Canada, the United States, South Africa, and India. The global flavour of his legal research has greatly enriched both Lord Cooke's legacy and New Zealand's jurisprudence.

\section{EXTRAJUDICIAL WRITING}

Through reading and writing abstracts for each of Lord Cooke's papers, we have come to appreciate not only the breadth of Lord Cooke's legal experience and distinctive writing style, but also the value of extrajudicial writing generally. Such writing allows judges to comment fruitfully on the development of the law outside the formal confines of a given case or judgment. ${ }^{5}$ It also

3 Please visit the Lord Cooke Project's SSRN page by searching for Robin Cooke (1926-2006) at $<$ http://papers.ssrn.com >.

4 See for example, Sian Elias "Eulogy for the Lord Cooke of Thorndon" (2008) 39 VUWLR 1 at 5 ["Eulogy for Lord Cooke"]; and Dean Knight "Simple, Fair and Discretionary Administrative Law" (2008) 39 VUWLR 99 at 100-102.

5 Grant Hammond "Judges and Free Speech in New Zealand" in HP Lee (ed) Judiciaries in Comparative Perspective (Cambridge University Press, New York, 2011) 195-216. 
provides an avenue for judges to justify - or re-evaluate - the positions they have expressed in judgments, as indeed Lord Cooke did. ${ }^{6}$

Writing extrajudicially is not, however, without controversy. We need look no further for this reminder than Lord Cooke's papers. ${ }^{7}$ For instance, in "Fairness", Lord Cooke recorded his reservations about "extra-judicial disquisition on legal subjects or trends". ${ }^{8} \mathrm{He}$ also considered that extrajudicial writing may be unhelpful where judges "try to proselytise or, worse, to approach the decision of future cases primarily in the light of avowed commitment to a creed". 9 Separately, in "Struggle for Simplicity", Lord Cooke specifically warned that judges are critical of counsel citing to them their own extrajudicial writings for two reasons. First, "they are prone to overlook points without the advantage of hearing both sides". Secondly, it may threaten judicial impartiality "when counsel reads with enthusiasm what one has said free of the discipline of the judicial role". 10

Conversely, Lord Cooke also identified certain benefits of extrajudicial discussions. Some of these also appear in "Fairness", where, for example, Lord Cooke pointed out that extrajudicial writing may be helpful for judges where it "forces a more ordered and wider examination of the principles that one applies in day-to-day work". ${ }^{11}$ It is implicit from his prolific academic work that he considered extrajudicial writing to be of value for judges. However, his remarks in "Fairness" and other articles indicate that Lord Cooke was also conscious of the dangers of writing extrajudicially, especially where comments may be interpreted as treading too close to commenting significantly on pending cases or judgments (as, indeed, a number of Lord Cooke's extrajudicial comments can be interpreted). ${ }^{12} \mathrm{He}$ believed that the dangers of extrajudicial writing could be reduced where judges were conscious of them. ${ }^{13}$

6 See, for example, Lord Cooke "The British Embracement of Human Rights" [1999] EHRLR 243 at 250.

7 Robin Cooke "The Struggle for Simplicity in Administrative Law" in Michael Taggart Judicial Review of Administrative Action in the 1980s (Oxford University Press, Auckland, 1986) 1 ["Struggle for Simplicity"] at 1-2; Robin Cooke "An Impossible Distinction" (1991) 107 LQR 46 ["An Impossible Distinction"] at 47; Robin Cooke "Fairness" (1989) VUWLR 421 ["Fairness"] at 421; and Lord Cooke "Human Rights in Hong Kong" (1999) 29 VUWLR 45 at 46.

8 "Fairness", above n 7, at 421.

9 At 421 .

10 "Struggle for Simplicity", above n 7, at 1.

11 "Fairness", above n 7, at 421.

12 "Fairness", above n 7 at 427; "An impossible Distinction", above n 7, at 47; Robin Cooke "Bill of Rights Reports launch" [1993] NZLJ 123 at 123 ["Launch"]; Robin Cooke "A Sketch from the Blue Train - NonDiscrimination and Freedom of Expression: the New Zealand Contribution" (1993) 19 CLB 1782 ["Blue Train"] at 1785; see also "Human Rights in Hong Kong", above n 7, at 46.

13 "Fairness", above n 7, at 421. 
For these reasons, we consider that the Lord Cooke Project is a valuable resource for scholars, legal practitioners, the judiciary, and others in the legal profession. The same is true of extrajudicial writing generally. We now turn to our discussion on Lord Cooke's views on the three themes outlined above: his conceptions of the common law, his influence on particular areas of public law, and his understanding of the role of judges in the wider New Zealand constitutional context.

\section{CONCEPTIONS OF THE COMMON LAW}

In this section, we discuss three aspects of Lord Cooke's understanding of the common law evident from his extrajudicial writings. These aspects are Lord Cooke's advocacy for an end to the English-centred common law that New Zealand inherited, his articulation and adoption of a comparative approach to law, and his discussion of an international common law.

\section{A The End of the English-Centred Common Law}

Lord Cooke began practising at the New Zealand Bar in 1955. ${ }^{14}$ At this time New Zealand's legal development was still very much intertwined with England's. It was still accurate to treat the "common law" as being a source of law primarily emanating from and developed by the English courts. ${ }^{15}$ As Elias CJ discussed in her eulogy for Lord Cooke, "[i]t was not until the 1960s that New Zealand judges began to shed" what had been described as "essentially derivative thinking, hanging off the latest English cases". ${ }^{16}$ Lord Cooke, in his extrajudicial writing, was influential in advocating for this shift. This advocacy first appears in an article published in 1956, in which Lord Cooke suggested that an English-centred approach to the common law would not always be appropriate for New Zealand. ${ }^{17}$

In the decades that followed, Lord Cooke's position developed. New Zealand, spurred on by developments in sister common law countries, most notably Australia, began to develop its own legal identity. Lord Cooke recorded these developments some time afterwards in an article titled "Divergences - England, Australia and New Zealand". ${ }^{18}$ He commented that it was not until 1971 that the New Zealand Court of Appeal "finally decided that New Zealand would not automatically

14 For a discussion of the period Lord Cooke spent in Cambridge, and his return to New Zealand, see ATH Smith, above n 2 .

15 See, for example, Robin Cooke "Divergences - England, Australia and New Zealand" [1983] NZLJ 297 ["Divergences"]; Lord Cooke "The Dream of an International Common Law" in Cheryl Saunders (ed) Courts of Final Jurisdiction: The Mason Court in Australia (Federation Press, Sydney, 1996) 136 ["Dream"] at 143; and Lord Cooke "The Road Ahead for the Common Law" (2004) 53 ICLQ 273 ["Road Ahead for the Common Law"] at 273.

16 "Eulogy for Lord Cooke", above n 4, at 3.

17 Robin Cooke "The Supreme Tribunal of the British Commonwealth?" [1956] NZLJ 233.

18 "Divergences", above n 15. 
follow the House of Lords". ${ }^{19}$ Indeed, the Chief Justice acknowledged in her eulogy that the appointment of Lord Cooke to the judiciary in 1972 "was key to the development of a distinctive New Zealand jurisprudence from that time". ${ }^{20}$

These developments continued. According to Lord Cooke, by 1983 "a distinctive Australian identity" could be identified, fostered by the judiciary in that country. ${ }^{21}$ In the same article he recorded that "the ideal that the common law should be the same throughout the Commonwealth" was by then an "exploded hypothesis" (meaning that it was now proven false). ${ }^{22}$ Similar comments are expressed in other articles. For example, in "The Common Law Through Commonwealth Eyes" Lord Cooke noted that common law countries were, by the time of writing in 1998, "assertive" in taking a different approach to the English common law. ${ }^{23} \mathrm{He}$ subsequently referred to these developments as reflecting the "diminishing Englishness of the Common Law". ${ }^{24}$ A useful summary of how Lord Cooke understood the effect of this sea change is given by the following quote: ${ }^{25}$

\footnotetext{
Now it has become widely appreciated that there may be more ways than one in which national common law systems, starting from the same roots, may justifiably go. Different chains of reasoning and weightings of values may be reasonably open. Indeed United States legal history has long demonstrated that truth. For a decade and more it has been a commonplace that Australian and Canadian common law, for instance, are not necessarily the same as English common law. The same has been accepted recently by the Privy Council itself in relation to New Zealand.
}

As Lord Cooke acknowledged, the notion of a "New Zealand common law" did not develop suddenly. Rather, he observed that, from the 1960s onwards, particular judges and members of the profession were warming to this idea. ${ }^{26} \mathrm{He}$ referred in particular to North, Turner, and McCarthy JJ as having a "conscious appreciation of the need to develop a distinctively New Zealand identity". ${ }^{27}$

19 "Divergences", above n 15, at 298.

20 "Eulogy for Lord Cooke", above n 4, at 3.

21 "Divergences", above n 15 at 297.

22 At 299

23 Lord Cooke "The Common Law Through Commonwealth Eyes" (1998) 2 Inter Alia 45 ["Commonwealth Eyes"].

24 "Road Ahead for the Common Law", above n 15, at 273.

25 "Dream", above n 15, at 143 (footnotes omitted); see also "Robin Cooke "Fundamentals" [1988] NZLJ 158 ["Fundamentals"] at 299.

26 "Court of Appeal President: An Interview with Rt Hon Sir Robin Cooke" [1986] NZLJ 170 ["Interview"] at 174.

27 "Interview", above n 26, at 174, citing Bognuda v Upton \& Shearer Ltd [1972] NZLR 741 (CA); Jorgensen v News Media (Auckland) Ltd [1969] NZLR 961 (CA); and New Zealand Dairy Board v Co-operative Dairy Company Ltd [1953] NZLR 366 (CA). 
It is evident that the development of a distinct New Zealand legal identity was spurred on by Lord Cooke's observation that judges were in that period increasingly being asked to decide cases "of the semi-political or public controversy type". In such cases, the courts were "called upon to try, cautiously but nonetheless definitely, to evolve something in the nature of a New Zealand common law". ${ }^{28}$ Judges were asked to develop the law in grey areas in ways which seemed "best suited to the circumstances, environment and nature of this country". ${ }^{29}$ In deciding these difficult cases, the New Zealand courts had to forge their own legal path.

Following this, in 1987, Lord Cooke attempted to articulate his conception of New Zealand's common law, in an article titled "The New Zealand National Legal Identity". Here, Lord Cooke identified a wide range of different areas of law where New Zealand had developed a distinct legal identity, including criminal, family, property, contract law, and many other areas. ${ }^{30}$ Then, in the same article, he used the development of this distinct identity as an argument in favour of abolition of the right of appeal to the Privy Council from New Zealand and the establishment of an independent final appellate court. ${ }^{31}$ As he explained: ${ }^{32}$

New Zealand law, both that made by our parliament and that made by our judges, has now evolved into a truly distinctive body of principles and practices, reflecting a truly distinctive outlook. Common sense dictates the inevitable result. ... We must accept responsibility for our own national legal destiny and recognise that the Privy Council appeal has outlived its time. Not to take the obvious decision now would be to renounce part of our nationhood.

\section{B Comparative Approach to Common Law}

Throughout his career, Lord Cooke would often look to other jurisdictions to inform his understanding of New Zealand law (or the law of the other jurisdictions in which he sat). As his extrajudicial writings show, Lord Cooke adopted and articulated a comparative approach to the law. By a comparative approach, Lord Cooke meant that judges should be encouraged to draw on discussions and interpretations of law in other common law countries. For Lord Cooke, this

28 "Interview", above n 26, at 174; see also Robin Cooke "FW Guest Memorial Lecture: the Courts and Public Controversy" (1983) 5 Otago L Rev 357 ["Courts and Public Controversy"] for further comments on deciding controversial cases.

29 "Interview", above n 26, at 174.

30 Robin Cooke "The New Zealand National Legal Identity" (1987) 3 Canta LR 171 ["New Zealand National Legal Identity"].

31 "New Zealand National Legal Identity", above n 30, at 180-183; see also "Blue Train", above n 12, at 1788.

32 "New Zealand National Legal Identity", above n 30, at 182-183. 
argument flowed naturally from the recognition that separate common law jurisdictions had distinct approaches to developing their law. ${ }^{33}$

This comparative approach is evident even in his earliest writings. For example, in 1954, Lord Cooke drew on New Zealand decisions to assess contemporaneous English decisions in a series of case notes for the Cambridge Law Journal. ${ }^{34}$ Other examples of a comparative approach appear from Lord Cooke's regular updates on New Zealand administrative law, in which he would compare and contrast New Zealand's developments in this field with those in other common law countries, ${ }^{35}$ and his approach to the interpretation of the NZBORA. ${ }^{36}$

As New Zealand became more confident in forming its own legal identity, Lord Cooke saw a wider role for other common law countries to influence the development of the common law in this country. ${ }^{37}$ Moreover, at the same time as the common law was becoming less overbearingly English in its nature, the English courts themselves were becoming more willing to view other nations' judicial decisions as valuable sources of comparative law. ${ }^{38} \mathrm{He}$ also argued that the common law countries should support the establishment of a "common lawyer's airmail weekly". He intended that this publication would update lawyers on recent developments in relevant jurisdictions. Arguably, this suggestion has been given life by the electronic age. ${ }^{39}$

33 See for example, "Fundamentals", above n 25; "Dream", above n 25, 142-145; and "Commonwealth Eyes" above $\mathrm{n} 23$.

34 Robin Cooke "Administrative Law - Natural Justice - Right to a Hearing" [1954] CLJ 14; Robin Cooke "Solicitor Client - Privilege - Statutory Interpretation" [1954] CLJ 156; and Robin Cooke "Crown Servants - Immunity From Taxation" [1943] CLJ 159.

35 Robin Cooke "The Changing Face of Administrative Law" [1960] NZLJ 128; Robin Cooke "Administrative Law: The Vanishing Sphinx" [1975] NZLJ 529 ["Vanishing Sphinx"]; Robin Cooke "Third Thoughts on Administrative Law" [1979] NZ Recent Law 218; and Lord Cooke "Administrative Law Trends in the Commonwealth" in Visu Sinnadurai (ed) The Sultan Azlan Shah Law Lectures: Judges on the Common Law (Thompson Sweet \& Maxwell Asia, Kuala Lumpur, 2004) 105.

36 "Launch", above n 12, at 124 and "Dream", above n 15, at 142-143.

37 See generally "Fundamentals", above n 25; Robin Cooke "Dynamics of the Common Law" (9th Commonwealth Law Conference, Auckland, April 1990) ["Dynamics"]; and "Dream"; above n 25, at 142 145 .

38 "Commonwealth Eyes", above n 23, at 47; "Dream", above n 25, at 142.

39 "Divergences", above n 15, at 303; see also Dean Knight, above n 4, at 100; Graham Greenleaf, Andrew Mowbray, and Philip Chung "A New Home Online for Commonwealth Law: A Proposal for a CommonLII" [2004] JILT, in which they refer favourably to several of Lord Cooke's extrajudicial writings. 
Lord Cooke's comparative approach was not jingoistic. At times Lord Cooke criticised New Zealand's approach to particular legal issues when comparing it to other jurisdictions. ${ }^{40}$ However, although he considered that New Zealand and, indeed, all common law countries could benefit greatly from a comparative approach, this had its limit. As Lord Cooke emphasised in "Divergences", where different views were possible, New Zealand should ultimately adopt the solution that would be most consistent with local legal developments and social values. ${ }^{41}$

\section{Articulation of an International Common Law}

Lord Cooke's musings on the common law went one step further. Unsatisfied with advocating for both an end to an English-centred common law and the development of a comparative approach between jurisdictions, in his later writings Lord Cooke began articulating what he referred to as an "international common law".

As he admitted, his advocacy for this idea was somewhat paradoxical, given his strongly held views that each legal system should be permitted to develop in accordance with its own circumstances and values. ${ }^{42}$ However, he argued that overarching all of these independent common law legal systems were fundamental values which each system would necessarily accept. Lord Cooke believed that these fundamental values would eventually be recognised as an international common law. As he explained in "The Dream of an International Common Law":43

[E]mancipation does not mean abandonment of co-operation to mutual advantage. Common denominators may be usefully sought, as long as the process is not compelled from outside and the national ethos is allowed its own weight.

Lord Cooke's idea of an international common law was articulated in a series of papers from 1990 onwards. ${ }^{44}$ In these papers, most significantly in "The Judge in an Evolving Society", Lord Cooke referred to three developments in law that he considered provided evidence of an evolving international common law. These developments were as follows:

40 See for example, Robin Cooke "The Condition of the Law of Tort" in Peter Birks (ed) The Frontiers of Liability Vol 2 (Oxford University Press, Oxford, 1994) 49; "The British Embracement of Human Rights", above n 6; and "Administrative Law Trends in the Commonwealth", above n 35, at 29-30.

41 "Divergences", above n 15, at 299 and 303.

42 "Dream", above n 15, at 143

43 At 143 .

44 "Dynamics", above n 37, at 3; Robin Cooke "Party Autonomy" (1991) 30 VUWLR 257 ["Party Autonomy"]; "Dream", above 15; Lord Cooke "The Judge in an Evolving Society" (1998) 28 VUWLR 487 ["Judge in an Evolving Society"]; and "Human Rights in Hong Kong", above n 7. 
(a) The first was an increasing level of "cross-fertilisation" by judges in which judicial reasoning was supplemented by reference to decisions in other jurisdictions. ${ }^{45}$ Lord Cooke also pointed out that "even when cross-fertilisation is not ostensibly present or is unacknowledged, the international commerce of judicial ideas can be seen at work". ${ }^{46}$

(b) Lord Cooke viewed the development of a new lex mercatoria as a second relevant development. He understood this concept to refer to a body of internationally applicable principles that had emerged as a result of the internationalisation of commerce. He saw the growth of international commerce and international arbitration as leading to greater convergence in judicial approaches to cross-border contractual disputes. ${ }^{47}$

(c) The third significant development for Lord Cooke was the increasing recognition given to human rights in a number of jurisdictions. For Lord Cooke these developments were "encapsulated at the most general level in the Universal Declaration of Human Rights", a document recognised by the vast majority of nations across the world. ${ }^{48}$ As Lord Cooke commented separately: "[a]ll democratic nations contribute to the universal law" of freedom of speech and other human rights, which are "slowly but inevitably evolving". 49

Interestingly, Lord Cooke viewed Hong Kong, following the handover to China in 1997, as a potential example of the growth of international common law. Writing in "Human Rights in Hong Kong" in 1999, drawing on his experience as a Judge on the Hong Kong Court of Final Appeal, Lord Cooke noted that China had recognised the basic principles of tort, contract, and administrative law in the passage of particular legislation in Hong Kong. He considered this legislation to be "cogent evidence that, very gradually but inevitably, mankind is moving toward a common law of the world". 50

For Lord Cooke, developments in these three areas in common law legal systems gave him hope that the common law nations were gradually recognising an international common law. Each of these three areas continues to develop. The comparative approach Lord Cooke advocated is commonplace in New Zealand and across much of the rest of the common law world now. International arbitration and the development of common rules governing this area of law continue

45 "Judge in an Evolving Society", above n 44, at 147.

46 "Dream", above n 15, at 142

47 "Dynamics", above n 37, at 3; "Dream", above n 15, at 140-142; "Judge in an Evolving Society", above n 44, at 149; and see generally "Party Autonomy", above n 44.

48 "Judge in an Evolving Society", above n 44, at 149; see also "Dream", above n 15, at 139-140.

49 "Blue Train", above n 12, at 1788.

50 "Human Rights in Hong Kong", above n 7, at 52. 
to evolve, as do standard rules governing particular contractual disputes across borders. ${ }^{51}$ Moreover, more countries than ever have now ratified the Universal Declaration on Human Rights, and the importance of human rights is increasingly recognised in common law countries.

\section{AREAS OF INFLUENCE IN PUBLIC LAW}

No effort is made in this paper to fully canvass Lord Cooke's influence in public law. Indeed, others have already made admirable efforts in this area, ${ }^{52}$ and Lord Cooke himself provided a range of accessible material summarising his views. ${ }^{53}$ This section focuses on his influence in two controversial and highly influential areas of New Zealand public law: the interpretation of the Treaty of Waitangi and the New Zealand Bill of Rights Act 1990.

\section{A Treaty of Waitangi}

Lord Cooke made a significant impact in an area of public law unique to New Zealand: Treaty of Waitangi jurisprudence. In relation to this, Lord Cooke's extrajudicial writings are useful in showing the importance Lord Cooke placed on the Treaty and in articulating what he saw as the role judges should play in interpreting this constitutional document. Lord Cooke discussed the Treaty in a range of extrajudicial writings. ${ }^{54}$

New Zealand's approach to the Treaty, although unique, resembles and reflects developments in other legal systems dealing with indigenous rights. This was recognised by Lord Cooke in "Back on the Rails". Here, Lord Cooke refers to New Zealand as a world leader in indigenous rights, remarking that in the 1980s and 1990s the "interaction between parliamentary, government and

51 See for example, Sale of Goods (United Nations Convention) Act 1994; and Katrina Winsor "What is the CISG?" [2011] NZLJ 31.

52 See for example, Knight, above n 4 (although Knight also eschews attempting a comprehensive summary of Lord Cooke's influence in this area); see also the additional articles in this issue of the Victoria University of Wellington Law Review, above n 1, published to commemorate the life of Lord Cooke.

53 See for example, the papers referred to above at n 7 and 35 and Lord Cooke "The Discretionary Heart of Administrative Law" in C Forsyth and I Hare (eds) The Golden Metwand and the Crooked Cord: Essays in Honour of Sir William Wade (Oxford, Clarendon Press, 1998) 203; and "Road Ahead for the Common Law", above n 15.

54 "Blue Train", above n 12, at 1790-1792; Robin Cooke "Back on the Rails" [1995] NZLJ 393 at 393 ; "Fairness", above n 7, at 424-425 ; Robin Cooke "Introduction" (1991) 14 NZULR 1 ["Introduction"]; Robin Cooke "The Harkness Henry Lecture: the Challenge of Treaty of Waitangi Jurisprudence" (1994) 2 Waikato L Rev 1 ["The Challenge of Treaty Jurisprudence"]; Lord Cooke "Book review: Waitangai and Indigenous Rights: Revolution, Law and Legitimation by FM Brookfield" (2003) 119 LQR 326; "Dynamics", above n 37, at 5-7; Robin Cooke "Notes for Address of Right Hon Sir Robin Cooke, KBE, President of the Court of Appeal" (paper presented at Hui Manawheuna, Rotorua, April 1990); and "Fundamentals", above n 25, 1328-1329. See also PG McHugh "Treaty Principles: Constitutional Relations Inside a Conservative Jurisprudence" (2008) 39 VUWLR 39. 
judicial forces [had evolved] a concept of partnership between races and securing redress for colonial wrongs". 55

The particular importance Lord Cooke placed on the Treaty is expressed in his introduction to a special issue of the New Zealand Universities Law Review dedicated to the Treaty. In this article Lord Cooke comments that, although the status of the Treaty was not clearly defined in a legal sense, its importance was at that point "undeniably growing". ${ }^{56} \mathrm{He}$ described the Treaty as "simply the most important document in New Zealand's history", and comments that even those who view the Treaty as a threat must "[reluctantly recognise] that it has become the essence of the national life". 57

Lord Cooke also considered that the judiciary had a significant role to play in the interpretation of the Treaty. He articulated the "challenge" of Treaty jurisprudence as being the problems judges faced in working out how to, first, define the principles of the Treaty and, secondly, ensure that these principles had practical effect. In "The Harkness Henry Lecture: the Challenge of Treaty of Waitangi Jurisprudence" Lord Cooke commented that judges were, at the time of writing in 1994, showing "increased willingness" to use the language of the Treaty and the fiduciary concept to conceptualise the relationship between Māori and the Crown. ${ }^{58}$ In his address to Hui Manawhenua, he stressed two aspects of the role of the courts in Treaty jurisprudence. First, and generally, the courts should provide assurance that the legal rights of all sections of the community would be impartially worked out. Secondly, and specifically, they should encourage the Crown and Māori to settle their disputes through negotiation in good faith and in the spirit of partnership. ${ }^{59}$ However, ultimately, Lord Cooke recognised that the solution to race relations issues arising from the Treaty did not lie with judges, but rather "in the hearts and minds and circumstances of the people of New Zealand". ${ }^{60}$

\section{B New Zealand Bill of Rights Act 1990}

Turning now to another area of public law, Lord Cooke's extrajudicial writings make his early and strong advocacy for a New Zealand bill of rights and for similar human rights legislation across

55 "Back on the Rails", above n 54, at 393. See also Lord Cooke "Unicameralism in New Zealand: Some Lessons" [1997] Canta LR 233 ["Unicameralism in New Zealand"] for Lord Cooke's account of the history of New Zealand's constitutional structures.

56 "Introduction", above n 54, at 1.

57 At 1 .

58 "The Challenge of Treaty Jurisprudence", above n 54, at 11.

59 "Hui Manawhenua", above n 54.

60 At 4 . 
the common law world evident. ${ }^{61}$ For instance, following the publication of the 1985 White Paper mooting a bill of rights for New Zealand, Lord Cooke spoke out in favour of its passage the following year. These comments were given at the launch of a book critiquing the White Paper, titled A Standard for Justice. Given that opposition to the White Paper "stems from so many different quarters and invokes so many different reasons", Lord Cooke considered that "one obvious inference" remained: "The White Paper must have got the balance about right. A Bill of Rights that favours no one interest group cannot be all bad." 62

Similar affirming comments were given two years later in "Fundamentals". ${ }^{63}$ In this article, Lord Cooke gave three reasons for supporting a bill of rights for New Zealand. First, his support for the bill of rights flowed naturally from a genuine belief in the rights and freedoms set out in the proposed bill of rights. Secondly, a bill of rights seemed to him to be an appropriate modern update to the values expressed in the Magna Carta or Bill of Rights 1689 (UK). He considered that a bill of rights would be a "unifying expression of values accepted by the whole community". Finally, Lord Cooke hoped that the bill of rights would be a safeguard of sorts against New Zealand's "thin" unicameral legislature. ${ }^{64}$

As the final reason indicates, the bill of rights proposed in the 1985 White Paper - and, significantly, the particular bill of rights supported by Lord Cooke in the late 1980s - would have entrenched the bill of rights as supreme legislation for New Zealand, capable of overriding contrary legislation. ${ }^{65}$ However, Lord Cooke correctly predicted that New Zealand would likely adopt a weaker "fallback position" if Parliament decided to pass a bill of rights at all. ${ }^{66}$ Ultimately, New Zealand enacted a bill of rights in 1990 as the NZBORA. It was neither entrenched nor enacted as supreme law. Instead, s 4 of the NZBORA provides that enactments which are inconsistent with the NZBORA are not invalidated by virtue of that inconsistency. However, s 6 does require the courts to give a meaning to a provision that is consistent with the NZBORA where possible.

Lord Cooke's influence on the interpretation of the NZBORA in its early years was monumental. As a member of the Court of Appeal in the early and mid-1990s, Lord Cooke presided over the first

61 See for example, Robin Cooke "A Standard for Justice" [1986] NZLJ 149 ["A Standard for Justice"]; "Blue Train", above n 12; "The New Zealand National Legal Identity", above n 30, at 180-181; Robin Cooke "Brass Tacks and Bills of Rights" (1995) 25 Hong Kong LJ 64; "Judge in an Evolving Society", above n 44; "Human Rights in Hong Kong", above n 7; and "The British Embracement of Human Rights", above n 6.

62 "A Standard for Justice", above n 61, at 149

63 "Fundamentals", above n 25, at 159

64 Lord Cooke also separately commented on New Zealand's shift to a unicameral legislature in "Unicameralism in New Zealand", above n 55.

65 G Palmer "A Bill of Rights for New Zealand: A White Paper" [1984-5] I AJHR A6 at [3.11]. 
cases which called for the legislation's interpretation. He discussed this experience soon afterwards in a series of papers. ${ }^{67}$ In 1993, Lord Cooke referred to the enactment of this legislation as the "greatest change in New Zealand law in the last four years or so", speaking to an audience he had previously addressed in 1989.68

Interestingly, soon after the NZBORA's enactment, Lord Cooke appeared cautiously optimistic about the "fallback" position that had been adopted by Parliament. Speaking at the launch of the New Zealand Bill of Rights Reports in 1993, he commented:69

It may be that this [fallback position] will prove to be something of a masterstroke: a solution ensuring that the affirmed rights and freedoms do not dwarf all other considerations but conducing to their general prevalence and helping to ensure that departure from them will be only for the clearest and most compelling of reasons. In a way that is the autochthonous feature of the New Zealand Bill, and at this fairly early stage, I suspect that, by good fortune perhaps, it may be one of its greatest strengths.

In later years his position hardened against this weak solution. This may be considered unsurprising, given Lord Cooke's view of the role of the judiciary and his description of parliamentary sovereignty, discussed below. ${ }^{70}$ Lord Cooke's latter position on the NZBORA is reflected in his comments critiquing the New Zealand Act against the then proposed United Kingdom equivalent, the Human Rights Bill (now the Human Rights Act 1998 (UK)). He noted, for example, that "[t]he concept of declarations of incompatibility" proposed in the [UK] Bill was "an advance on the New Zealand Act". ${ }^{71}$ He also subsequently acknowledged the NZBORA as "the weakest solution" available to a country wishing to adopt a bill of rights. ${ }^{72}$

From the above, it is clear that Lord Cooke was a strong advocate of the NZBORA, even if he wished New Zealand had enacted a more powerful piece of legislation. His support for

67 Lord Cooke later commented on his views, including his judicial experiences, in relation to the NZBORA in a number of articles including the following: "Blue Train", above n 12; Robin Cooke "Australian Law Teachers' Association Annual Conference 1993 Opening Address" (1993) 5 Cant LR 203 ["Opening Address"]; "Dream", above n 15, at 142-143; Lord Cooke "Mechanisms for Entrenchment and Protection of a Bill of Rights: The New Zealand Experience" (1997) 5 EHRLR 490-495; and "Road Ahead for the Common Law", above n 15 , at 279.

68 "Opening Address", above n 67, at 203.

69 "Launch", above n 12, at 124.

70 "Fundamentals", above n 25; Robin Cooke "Empowerment and Accountability: the Quest for Administrative Justice" (1992) 18 CLR 1326 ["Empowerment and Accountability"]; Lord Cooke "Basic Themes" (2004) 2 NZJPIL 113 ["Basic Themes"]; and Lord Cooke "The Myth of Sovereignty"(2005) 3 NZJPIL 39 ["Myth of Sovereignty"].

71 "The British Embracement of Human Rights", above n 6, at 254.

72 "Human Rights in Hong Kong", above n 7, at 46-47; see also "Myth of Sovereignty", above n 70, at 43. 
entrenchment remains particularly significant today in light of New Zealand's current conversation about constitutional reform.

\section{ROLE OF JUDGES}

The final section of this note describes how Lord Cooke conceptualised the role of judges in his extrajudicial writings. Lord Cooke's discussions in this area are significant because judges inevitably deal with controversial issues. Lord Cooke believed that judges must, when adjudicating litigation touching major public controversy, try to master the "art of neither being too far ahead nor too far behind general community opinion - itself often a myth and even when not hard enough to gauge". ${ }^{73}$ The most important judicial quality, Lord Cooke believed, was an "understanding impartiality". He remarked that true impartiality did not come easily or naturally: it had to be strived for. ${ }^{74}$ As mentioned earlier, impartiality in determining disputes between the Crown and Māori in the context of Treaty jurisprudence was a particular challenge in the New Zealand context.

The final section of this note highlights two particular ways in which Lord Cooke's conception of the role of the judiciary is significant and worthy of further consideration. First, his caution about avoiding elegant technical solutions, and instead focusing on clarity and simplicity when articulating legal concepts, serves as sound advice for all decision-makers. Secondly, his rejection of parliamentary sovereignty and commensurate view of the significant constitutional safeguard provided by the judiciary offers valuable academic fodder for examining the relationship between the three branches of government.

\section{A Focus on Clarity}

One particular area in which Lord Cooke provided guidance to the judiciary is his focus on articulating clear, simple, and understandable legal principles. He suggested that the judiciary - and, by extension, advocates appearing before them - should advocate straightforward legal arguments, shorn of technicalities and needlessly elaborate conceptions of the law ${ }^{75}$ Lord Cooke also stressed that he was advocating for "[s]implicity of principle or doctrine, not, of course, of the subject-matter and problems to which the principles or doctrines fall to be applied". ${ }^{76}$ This is because, as he noted elsewhere, "[t]he untidiness of life is forever overruling elegance" ${ }^{77}$ Given the untidiness and often

73 "Courts and Public Controversy", above n 28, at 365.

74 At 366.

75 See generally "Fairness", above n 7; "Struggle for Simplicity", above n 7; and Lord Cooke "The Temptation of Elegance Resisted" in Robin Cooke The Hamlyn Lectures: Turning Points of the Common Law (Sweet \& Maxwell, London, 1997) 48 ["Temptation of Elegance Resisted"].

76 "Struggle for Simplicity", above n 7, at 2.

77 "Temptation of Elegance Resisted", above n 75, at 62. 
technical nature of factual scenarios before judges, the need for clarity in legal principles was particularly important, as Lord Cooke realised.

This focus on clarity is clear in Lord Cooke's extrajudicial writing in both tort and public law. For example, in one of his Hamlyn Lectures, "The Temptation of Elegance Resisted", Lord Cooke discussed three examples in which "the untidy complexity of life ... led the House of Lords to resist the temptation of elegance" ${ }^{78} \mathrm{He}$ argued that courts should avoid elegant solutions in the law of negligence, particularly when assessing tortious liability for economic loss. ${ }^{79}$ Lord Cooke emphasised that, although progress is not measured by an expansive approach to negligence (that is, in favour of the plaintiff), judges do have a creative role to play in developing legal frameworks for resolving complex tort issues. Lord Cooke provided similar comments in relation to additional areas of tort law in other articles. ${ }^{80}$

The same message was stressed by Lord Cooke in public law. ${ }^{81}$ In "The Struggle for Simplicity in Administrative Law" Lord Cooke commented that, given the difficult and variable nature of public law disputes, "it is all the more important not to add to the exercise by superfluous complications of principle". He considered that "[o]bsure concepts hinder progress" and that there was therefore a very real practical reason for formulating a simple articulation of administrative law. Lord Cooke went on to summarise that "the substantive principles of judicial review are simply that the decision-maker must act in accordance with law, fairly and reasonably". As he later pointed out, "[t]hat is the essence and the rest is mainly machinery". ${ }^{82}$

This focus on clarity in judges' articulations of the law links to a further concept advocated by Lord Cooke, both in "Struggle for Simplicity" and, more notably, "Fairness". As set out in these papers, Lord Cooke believed that the ideal of fairness and a sense of what it requires should collectively be a guiding force in the development of the law. He disputed that a focus on fairness,

78 At 53

79 "Temptation of Elegance Resisted", above n 75, at 52-61, referring to Hedley Byrne \& Co Ltd v Heller \& Partners Ltd [1963] AC 465 (HL) and related cases.

80 Robin Cooke "Remoteness of Damages and Judicial Discretion" (1978) 37 CLJ 288; Robin Cooke "Tort and Contract" in PD Finn (ed) Essays on Contract (Law Book Company Limited, Sydney, 1987), 222-232; and "An Impossible Distinction", above n 7.

81 "Vanishing Sphinx", above n 35, at 530, referring approvingly to Lord Reid's "steadfast adherence to simple principles" in his administrative law judgments; "Struggle for Simplicity", above n 7; "Fairness", above n 7 , at 422-423; Robin Cooke "Empowerment and Accountability: the Quest for Administrative Justice" (1992) 18 CLR 1326 ["Empowerment and Accountability"] at 1326; and Lord Cooke "The Liberation of English Public Law" in Lord Cooke The Hamlyn Lectures: Turning Points of the Common Law (Sweet \& Maxwell, London, 1997) 63.

82 "Empowerment and Accountability", above n 81, at 1326. 
particularly in hard cases, would necessarily produce more uncertainty. ${ }^{83}$ In "Fairness", Lord Cooke reviewed the Court of Appeal's decisions in the fields of Treaty jurisprudence, administrative law, employment law and constructive trusts, to emphasise the importance of fairness. He argued that where the law produces an unfair result the law has failed. Lord Cooke hoped that "the criterion of fairness can produce more certainty than the a priori arguments of technically learned lawyers". ${ }^{84}$ As he later stressed on a similar note, "fair means fair" and "reasonable means reasonable". ${ }^{85}$

This focus on clarity and simplicity provides valuable guidance for all those practising law. Lord Cooke's guidance should lead scholars, practitioners, and judges alike to focus on the purpose behind legal principles and the impact these principles will have both on the particular parties to a dispute and to wider public policy factors.

\section{B Judiciary as a Constitutional Safeguard}

Lord Cooke also recognised that the judiciary served as a significant constitutional safeguard. He saw the role of judges as including being part of a collaborative enterprise with Parliament and the Executive to ensure that all branches of government operated in accordance with the rule of law. In "The Myth of Sovereignty", Lord Cooke rejected the notion that one organ of government, Parliament, should be supreme. He argued instead that the "sovereignty concept may be largely replaced by one of interaction, of checks and balances, of some degree of competition". ${ }^{86}$ In the same article, he referred to parliamentary sovereignty as a "myth" reflecting a "common illusion, tidy but superficial". He also described the inclusion of the "sovereignty of Parliament" in the Supreme Court Act $2003^{87}$ as being "incongruous" and expressed similar views of collaboration between the political and judicial branches in other articles. ${ }^{88}$

Lord Cooke's view of the judicial role should not, however, be mistaken for endorsing a rival judicial supremacy. His view was more nuanced. He viewed democracy as being the bedrock of New Zealand society: it was the "supremacy, sovereignty or plenary power of [Parliament] that the Courts accept[ed]". ${ }^{89}$ As Lord Cooke discussed, Parliament enacts law and the courts must interpret what Parliament enacts. As a result, although Parliament had broad limits to lay down policy, judges

83 "Fairness", above n 7.

84 "Fairness", above n 7, at 422.

"Struggle for Simplicity", above n 7, at 14.

86 "Myth of Sovereignty", above n 70, at 41. As acknowledged at page 41 of that article, Lord Cooke drew from the work of Philip A Joseph in this area.

87 "Basic Themes", above n 70, at 114; see also the Supreme Court Act 2003, s 3(2).

88 See for example, Robin Cooke "Road Ahead for the Common Law", above n 15, and "Myth of Sovereignty", above n 70 .

89 "Fundamentals", above n 25, at 163. 
retained an "inescapable judicial responsibility" to ensure that Acts of Parliament were consistent with fundamental rights. ${ }^{90}$ For Lord Cooke, therefore, constitutions, whether written or unwritten, contained basic fundamental aspects, including "the functioning of a democratically elected Parliament" and "the existence and functioning of independent courts". ${ }^{91}$

\section{CONCLUSION}

The above discussion highlights a selection of areas in which Lord Cooke has offered interesting insights in his extrajudicial writings. In light of the above discussion, we can offer the following four comments about, first, Lord Cooke specifically and, secondly, extrajudicial writing generally.

Lord Cooke's extrajudicial writings are firstly useful in recording the immense influence he has wielded across New Zealand's common law. For instance, his influence on jurisprudence relating to the Treaty and NZBORA are clear. Lord Cooke's contribution in these areas is recorded in judgments and by Lord Cooke himself in his extrajudicial writings. Further, these extrajudicial writings also offer insight into Lord Cooke's reflections on his role as a judge in interpreting these key constitutional documents, and provide guidance for scholars, practitioners, and judges seeking to interpret these documents in the future.

His writings are also valuable in a second way. Not only do they record and elaborate on specific areas in which Lord Cooke's influence is acknowledged, they also provide further areas in which Lord Cooke's views may be drawn upon to assist in the development of law in the future. For example, Lord Cooke argued for both an entrenched NZBORA and recognition that the constitutional safeguard role of the judiciary should, on the rarest occasions, allow for the striking down of legislation. To date, these arguments have not been accepted and adopted by the New Zealand legal system. They are, however, particularly important to refer to today, in light of the current conversation this country is having about its constitutional arrangements. Similarly, the concept of an "international common law" is a further area in which Lord Cooke's extrajudicial writings may offer valuable guidance in the future.

Thirdly, looking broadly across Lord Cooke's published papers, it is appropriate to acknowledge that in a number of areas he was correctly viewed as being progressive. His comparative approach to the law, specifically his willingness to draw not only upon the traditional common law jurisdictions of the United Kingdom, Australia, Canada and the United States, but on other countries including those in the Asia-Pacific region, is welcome. In this manner, his extrajudicial writings will assist future scholars in charting New Zealand's development as a common law country firmly centred in the Asia-Pacific. ${ }^{92}$ We hope that Lord Cooke will be an influential source in convincing the legal

90 "Fundamentals", above n 25, at 165.

91 At $163-164$

92 See also Michael Kirby "Robin Cooke, Human Rights and the Pacific Dimension" (2008) 39 VUWLR 119. 
profession to look outside New Zealand, but most specifically to sources of law in the Asia-Pacific to interpret and supplement New Zealand jurisprudence.

Our final comment relates to the perspective we can offer specifically as young members of the New Zealand legal profession. Throughout law school, the one judge students will universally be able to recall by name is Lord Cooke. He is held in high esteem by academics teaching future members of the profession. ${ }^{93}$ Our review of his published papers upholds the respected position Lord Cooke occupies in law schools. As is correctly taught to students, Lord Cooke did often strike out into new territories of law, as is evidenced by his early advocacy for a distinct New Zealand common law.

We encourage interested readers to read Lord Cooke's papers themselves and reach their own conclusions on the areas discussed in this paper. We have found the Lord Cooke Project to be valuable in developing a nuanced understanding of Lord Cooke and his contribution to New Zealand law.

93 See for example, Richard Sutton "Lord Cooke and the Academy: A View from the Law Schools" in Michael Taggart Judicial Review of Administrative Action in the 1980s (Oxford University Press, Auckland, 1986) 13. 